\title{
ORNAMENTS OF EMPOWERMENT \\ THE KUNDALA-SUBANG IN OLD JAVANESE JEWELLERY
}

The arts of Central and Eastern Java, spanning from the late $8^{\text {th }}$ to the $16^{\text {th }}$ centuries, are rich in visual imagery of jewellery and other forms of precious adornment. The icons of Hindu and Buddhist deities associated with the major religious cults of the period are depicted lavishly embellished with jewellery, which we know from the archaeological record represents precious metal items, most notably gold. Random accidental discoveries of ancient Javanese gold jewellery are reported from the beginning of the Dutch archaeological records under the Batavia Society and the Archaeological Service of the Netherlands East Indies (Oudheidkundig Verslag, 1912-1949), and thereafter by the Archaeological Service of Indonesia. The most significant finds include the Muturen hoard (1881) and more than a century later the Wonoboyo hoard (1990-91), the single most important discovery of Javanese gold artefacts to date. ${ }^{1}$ The cumulative record from Java is spectacular, far outnumbering the finds of antique jewellery in the Indian subcontinent for the equivalent period.

These items of adornment, be they for human or divine bodies, can assume many forms. Taken together they represent an elaborate ensemble of adornment: from head to toe the gods (and presumably the rulers on appropriate occasions) were dressed with crown and/or diadem (kiritamukuta), ear ornaments (kundala, pendant ear-rings and inserted ear-plugs), necklaces, pectorals (kanthi), sacred cords (yajnopavita / upavita), waistbands (udarabanda) waist-belts, armbands (keyura) and bracelets, anklets, and often rings worn on both fingers and toes.

This level of decoration would appear to go beyond the normal requirements of display of rank or status and reflects a higher need, one which has its origins in early Indian concepts of empowering the personage and enhancing the icon in order to attract the divine spirit to inhabit it. This is the concept of alamkara, the Sanskrit term for adornment or embellishment. ${ }^{2}$ The concept extends across the arts, from the enhancement of icons with temple jewellery and gilded textiles, to the use of expressive gesture in dance and the performing arts, to the elaboration of literary forms to enhance their complexity and beauty. In this short note, we are concerned with the role of jewellery to adorn temple icons and so enhance their efficacy.

The sculptural evidence for the prevalence of the concept of alamkara in early India is pervasive from almost the beginning of a figurative sculptural tradition, where we encounter an elaborate repertoire of jewellery being depicted. A recurring motif in the early images of the gods, and of patrons and other secular figures, is the circular ear-plug ornaments, henceforth

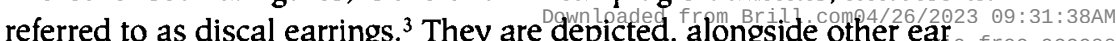



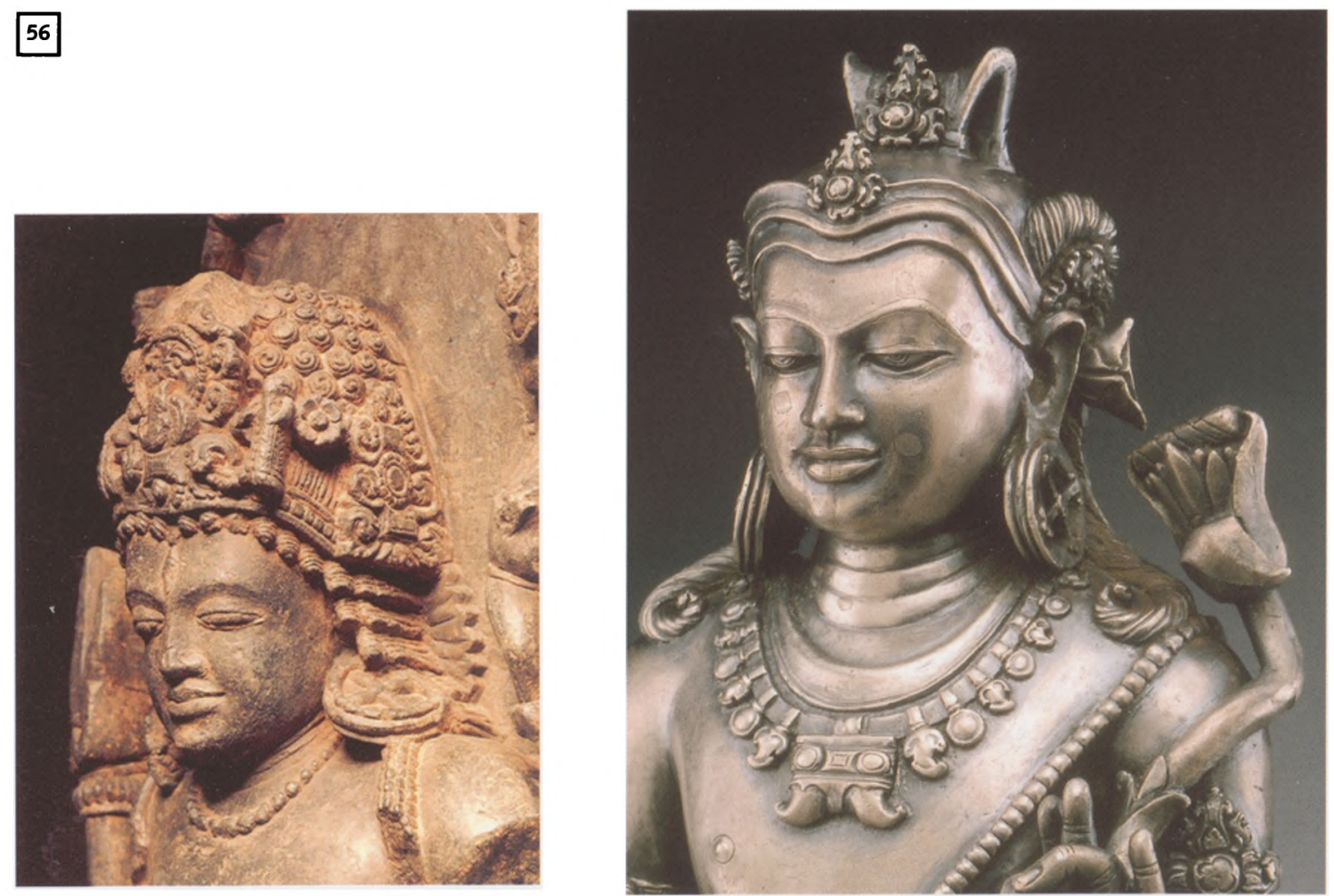

Figure 1 (left) Standing Shiva (detail showing kundala ear ornament), stone, Samalaji, Gujarat, Western India, early $6^{\text {th }}$ century, private collection

Figure 2

Bodhisattva Manjusri, silver, Central Java, from Semarang, early $10^{\text {th }}$ century, h. 29 cm., Nasional Museum, Jakarta ornament types, at sites extending from Chandraketugarh to Bharhut, Mathura, Bhaja, Ajanta, Gandhara and Begram. ${ }^{4}$ During the consolidation of the Gupta reign in the $5^{\text {th }}$ century we witness as the dominant form the large discal earring (kundala), typically with openwork decoration. A single discal earring is favoured as one of Shiva's principal ornaments, evoking his female aspect, and the pair is worn by Parvati to denote her married status, when they are known as tatankas. An early $6^{\text {th }}$-century standing Shiva from Samalaji, Gujarat, western India illustrates this late Gupta-era tradition (fig. 1). This Shiva, along with many other images from this and associated sites, displays differentiated earrings: a pendant-type worn in the proper right earlobe, and a discal type in the left. These are consistent with the male and female alignments of Shiva, most fully expressed in the Ardhanarishvara form where the right side represents the male aspect of his personality, the left his feminine aspect. ${ }^{5}$ In the Samalaji figures the kundala is represented as a large circular earplug with a four-spoked axial motif in the centre.

As we turn our attention to late $9^{\text {th }}-10^{\text {th }}$ century Central Java, we see precisely this same ornament being worn by the Buddhist Bodhisattva Manjusri, only here identical earrings are worn in both ears (fig. 2). Whilst the depiction of jewellery is universal in Javanese religious imagery, it is most abundant on icons of Buddhist Mahayanist deities, most notably Bodhisattvas, Taras and other forms of the goddess. Nor is it limited to the benign and beneficent deities; fearsome guardians and wrathful gods also display such splendid items. The consistent interest in adornment on Javanese religious statuary makes it clear that this was understood as a necessary enhancement, fulfilling the ritual requirements for alamkara. Dod from Brill.come4/26/2023 09:31:38AM 


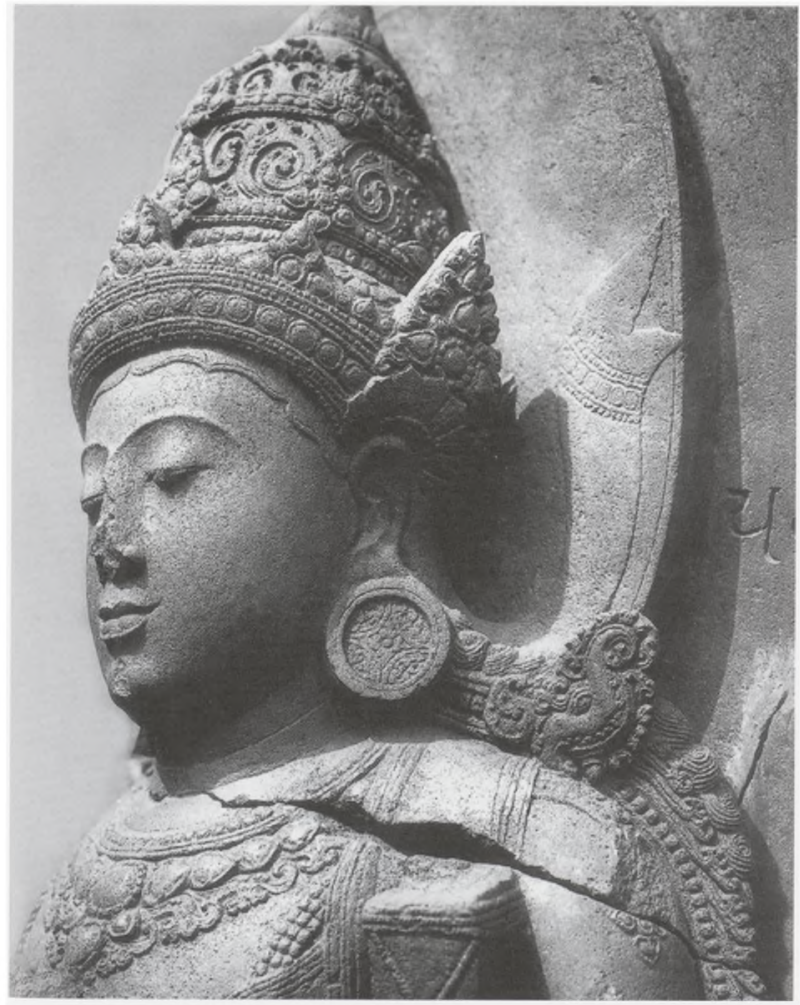

Figure 3

Bodhisattva

Sudhanakumara, Candi Jago, $13^{\text {th }}$ century, Nasional Museum, Jakarta. Photograph after J.L.A. Brandes, Archaeologisch Onderzoek op Java en Madura, dl I Tjandi

Djago, Batavia, 1904

Of all the forms of jewellery worn by the gods, it is the kundala or discal earring which has the longest unbroken tradition, both in India and in Hindu-Buddhist Indonesia. Whilst almost none of these divine and regal jewellery types have survived in India, we have a large corpus of such earrings from Java, dating to after the close of the Central Javanese period in the early $10^{\text {th }}$ century. ${ }^{6}$ Stylistic parallels with datable and dated monuments of the Singasari period (1222-1292), most notably Candi Jago (13 ${ }^{\text {th }}$ century) near Malang, and the Majapahit period (1292 - circa 1500) Panataran temple complex (1374), Blitar, securely anchor these earrings in the $13^{\text {th }}$ and $14^{\text {th }}$ centuries. We can be reasonably certain that such adornments were made in the intervening three centuries, but in the absence of archaeological or inscriptional evidence, this cannot be demonstrated. What is clear is that a dramatic stylistic shift occurred between the Central Javanese four-spoked type and the type we associate with the kingdoms of Eastern Java.

The East Javanese kundala, known locally as the subang, is constructed of a circular rim and two discs, one typically with openwork designs, which assemble to form a circular 'box', which has prompted speculation that they served a dual function, as ear-plug ornaments and as censers, the container perhaps being filled with sweet aromatics to please the wearer (a god), as the Sanskrit sastric ritual manuals instruct. ${ }^{7}$ The design structure that unifies this group is the consistent use of the radiating directional star form. It can be four-armed, denoting the cardinal directions, or sub-divided into eight, which together with the centre are read as the nine planetary deities, the navagraha, presiding over the dangerous moments of change in the cycle of time. 

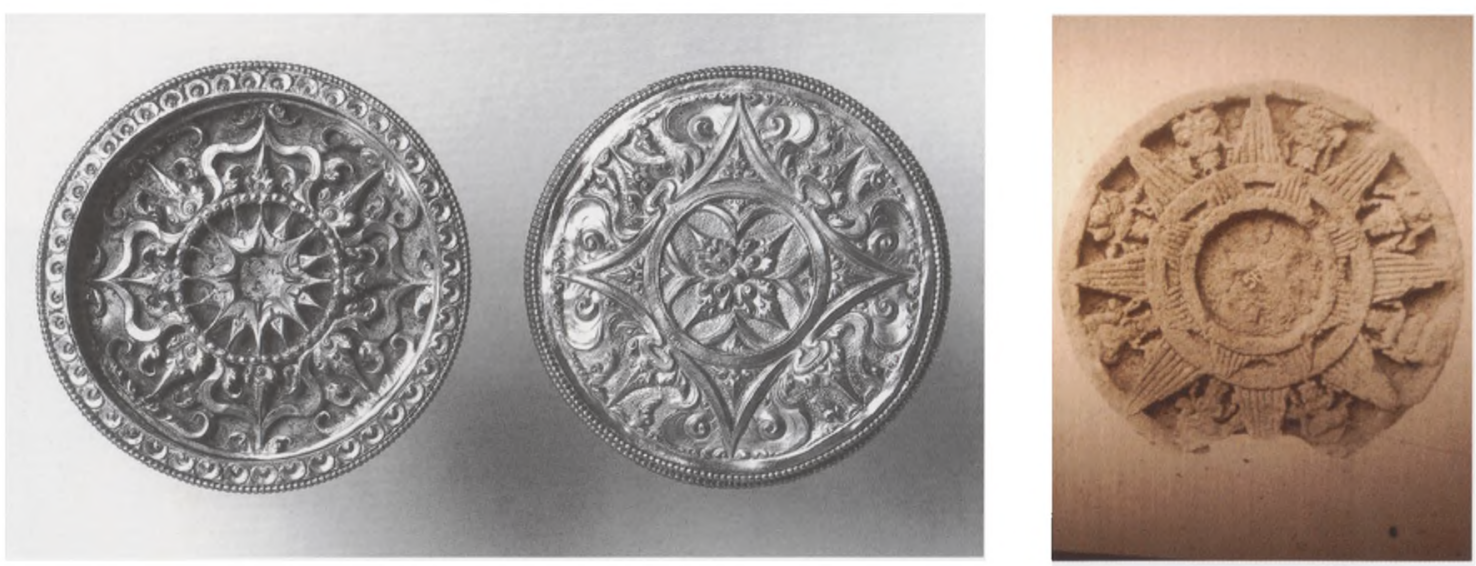

Figure 4 (left) Subang, discal earrings, gold and inset stones, Majapahit period, private collection, Amsterdam. Photograph courtesy of Documentation Centre for Ancient Indonesian Art, Amsterdam

Figure 5

Roundel depicting the planetary deities in a sunburst constellation, stone, East Java, c. $14^{\text {th }}$ century. Photograph after Oudheidkundige Dienst Archive

Figure 6 (opposite page) Subang, discal earrings, gold and inset stones, Majapahit period, Metropolitan Museum of Art, New York, bequest of Samuel Eilenberg and gift of Jonathan Rosen, 1998
The four-pointed star is the most common design on the earplugs, and is usually found on the reverse side. In Javanese culture this motif is familiar as the kawung, a motif of high status restricted by later court decrees to royal use within kraton circles. ${ }^{8}$ Its status in the Singasari period is confirmed by its representation on the pairs of subang worn by the sculptures of the Bodhisattva Sudhanakumara and the Syamatara from Candi Jago, datable to this period (fig. 3), and a related representation at Candi Kidal. One gold earring in a private Dutch collection confirms the efficacy of the Candi Jago representation (fig. 4). A Majapahit-period stone relief roundel demonstrates the planetary configuration, with the eight planetary deities set in double-ring sunburst, and the centre-axle for the ninth deity (fig. 5).

The Majapahit period subang are characterised by a flamboyant use of the vegetal, cloud and eye-motifs, some enhanced with animal or human forms, others with a conch (Vishnu's principal attribute). ${ }^{9}$ Where precious or semiprecious stones or rock crystal is added, they are held in a claw rather than in a bevelled setting, as is characteristic of Central Javanese period gold work. The pair in the Metropolitan Museum of Art is remarkable for the finely wrought female figures in foliate roundels and quatrefoil centres ringed with four inset stones (fig. 6). Others have rearing lions (fig. 7), devas or deer-like animals. The latter motif, an unidentified creature variously resembling a deer, goat or dog but with unnaturally enlarged ears, occurs on an openwork inset gold disc from a subang (fig. 8). This creature also occurs in bronze, sometimes with rider, sometimes without, and in temple reliefs, as seen on a relief medallion on a keystone at Candi Sawentar (circa 1388) where the representation of big-eared beast with nimbused male rider set in a flaming sun medallion, suggests identification with a solar deity (fig. 9).

The subang from Eastern Java are remarkable for the consistency of form and design elements, yet are configured in a variety of compositions to convey either sectarian allegiances, as with the use of Vishnu's conch, or favoured non-figurative designs, as with the numerous variations on the kawung pattern. The latter motif occurs widely as a textile pattern on the sculptures of the Singasari period, such as the seated Ganesha from Bara, near Blitar, dated equivalent to $1239 .{ }^{10}$ The fact that it is worn as the kain panjang of a deity underscores its high status in the early East Javanese period, and so its appearance in gold jewellery of the period should not be surprising. That the the 


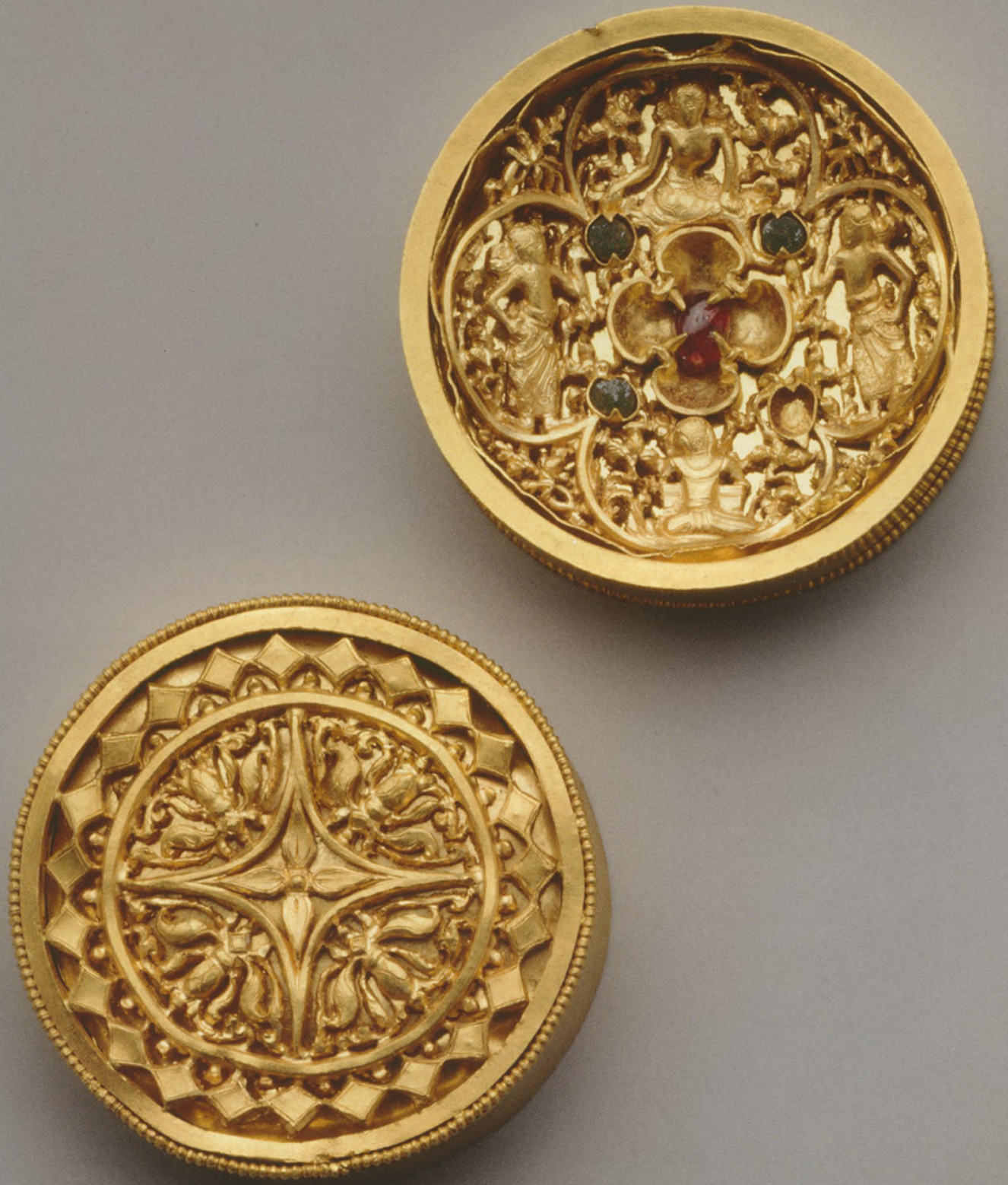



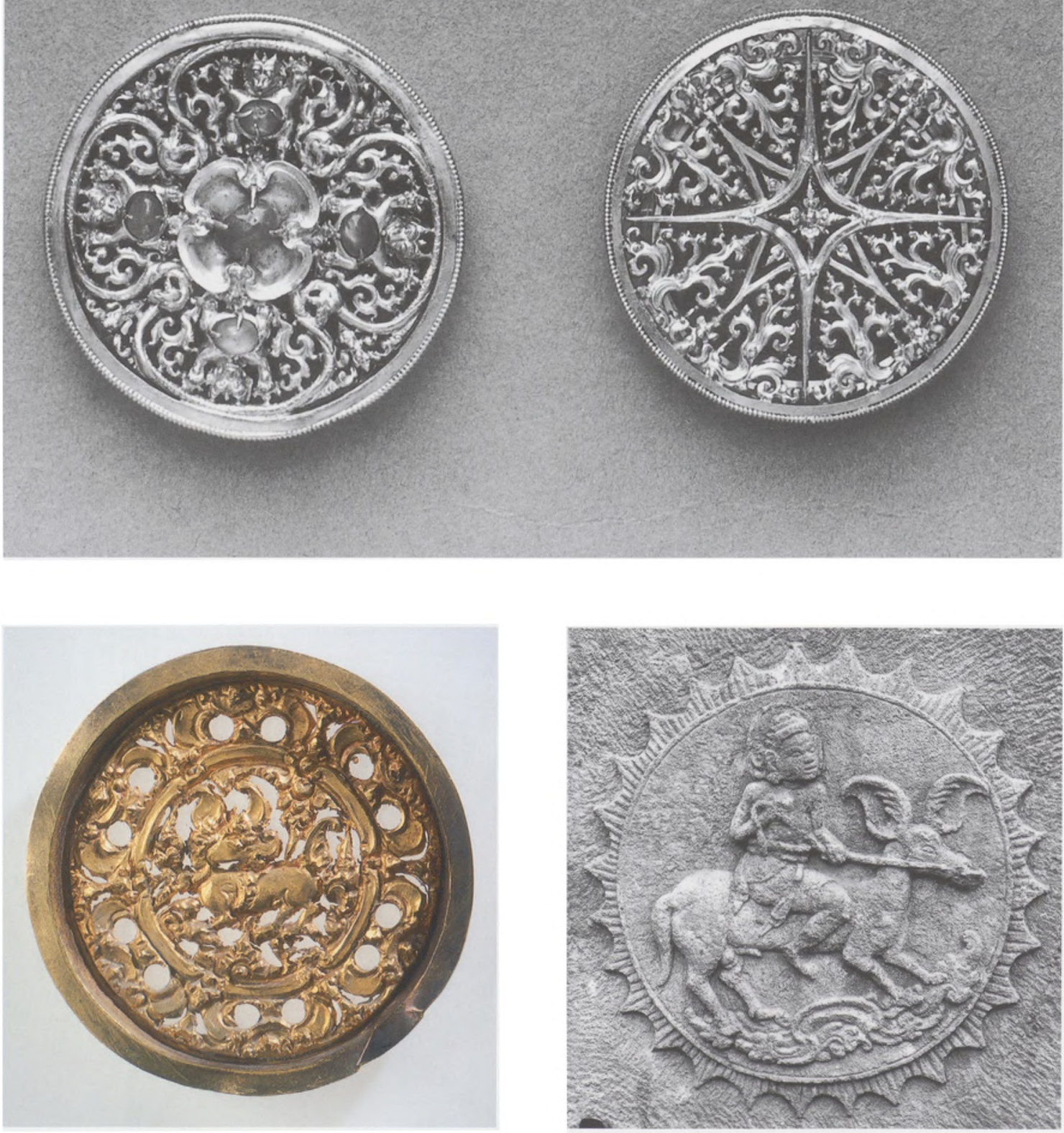

\section{Figure 8}

Subang, discal earring openwork insert with mythical creature in foliage design, gold, D. $5.8 \mathrm{~cm}$., Rijksmuseum Amsterdam, collection WAK, AK-MAK-1244
Figure 9

Relief depicting a divine rider on a mythical creature in clouds, Candi Sawentar, late $14^{\text {th }}$ century. Photograph after Oudheidkundige Dienst Archive 6879, courtesy of Documentation Centre for Ancient Indonesian Art, Amsterdam

Downloaded from Brill.com04/26/2023 09:31:38AM 
gold earrings that feature this motif were intended to be worn by human dignitaries, not sculptural representations of deities, underscores the high level of cross-over in the use of gold jewellery between the world of the gods

Figure 7 (left) Subang, discal earrings, gold and inset stones, Majapahit period, excollection Zorab, The Hague. Photograph courtesy of Documentation Centre for Ancient Indonesian Art, Amsterdam and man, with the latter wearing these adornments of the gods as both status indicators and talismanic protectors.

This briefest of excursions through the lineage of the discal earring from India to Eastern Java signals an important methodological issue, namely that surviving examples of Javanese gold jewellery may be studied not only for their own merit, but for the ways in which they may illuminate our understanding of early Indian temple jewellery, of which so very little has survived.

\section{Notes}

Acknowledgments: I am grateful foremost to Pauline Scheurleer and her writings for illuminating our understanding of Javanese design, and to Jaap Polak and the Documentation Centre for Ancient Indonesian Art, Amsterdam, for supplying photographs credited and for numerous valuable suggestions on this and related subjects relating to Javanese art.

1. P. Scheurleer, 'Oudheidkundige vondsten op Java', Aziatische Kunst 35/4 (2005), pp. 4-13, and Wahyono Martowikrido, 'The gold of Wonoboyo', in W.H. Kal (ed.) , Old Javanese Gold (4 $4^{\text {th }}-15^{\text {th }}$ century) (KIT Bulletin 334), Amsterdam, 1994, pp. 30-45.

2. A.K. Commaraswamy, 'Ornament', Art Bulletin 21 (1939), reprinted in R. Lipsey (ed.), Coomaraswamy. Vol. 1: Selected Papers; traditional art and symbolism, Princeton, 1977, pp. 241-53.

3. Following the term posited by M. Postal, Ear Ornaments of Ancient India, Bombay, 1989. An association with the enigmatic ring-stones of Shunga period, and a possible continuity of function, remains an open question beyond the focus of this paper.

4. For a rare late-Gandharan openwork disc with a hamsa design, very probably belonging to a kundala earring, see S. Eilenberg Gift, 1987, Metropolitan Museum of Art, New York.

5. J.Guy, 'The Divine Androgyne - Siva, Parvati and sexual syncretism in Indian art', in: J. Menzies (ed.), The Goddess; divine energy, Sydney/London, 2006, pp. 68-75.

6. C. 929 to be precise, based on the Wonoboyo coinage buried in the volcanic activity of that year, and which most probably represents the terminal date for cultural activity in Central Java.

7. As suggested by Jaap Polak; for sastric sources, see J. Guy, Indian Temple Sculpture, London, 2007.

8. A. Veldhuisen-Djajasoebrata, 'On the Origin and Nature of Larangan; forbidden batik patterns from the Central Javanese principalities', in: M. Gittinger (ed.), Indonesian Textiles, Washington DC, 1980, pp. 201-221.

9. For a detailed discussion of the treatment and evolution of these motifs, see P. Scheurleer, 'Meandering clouds for earrings', in: Kal, Op.cit. (note 1), pp. 18-29, and P. Scheurleer, 'An Introduction to Majapahit Ornamentation', Arts of Asia 30/6 (2000), pp. 85-96.

10. Although this sculpture may have been re-worked, including the addition of the inscription, in the East Javanese period, this object remains an important touchstone for demonstrating the prevalence and high status of the kawung design, see J. Guy, Woven Cargoes; Indian textiles in the East, London, 1998, pp. 62-63. 